Mongolian Academy of Sciences
Mongolian Journal of Chemistry
The Institute of Chemistry \& Chemical Technology

\title{
Biocatalytic properties of horseradish root extract peroxidase (HRP)
}

\author{
D.Purev ${ }^{1 *}$, J.Bayarmaa ${ }^{1}$, S.Tsevelmaa ${ }^{1}$, A.Zolzaya $^{2}$ \\ ${ }^{1}$ Department of Biology, School of Science, NUM, Ulaanbaatar, Mongolia \\ ${ }^{2}$ Medical Bioengineering Department, Etugen Instutite, Ulaanbaatar, Mongolia
}

ARTICLE INFO: Received 15 November 2014; revised 21 November 2014; accepted 01 December 2014

\begin{abstract}
The objective of the present work was to examine biocatalytic properties of peroxidase in horseradish acclimatized in our country. We have found that horseradish root extract's peroxidase (HRP) has $K_{M} 2.5 \mathrm{mM}$ and $\mathrm{V}_{\max } 5.36$ $\mathrm{mM} \cdot \mathrm{s}^{-1}$. Maximum activity $\left(\mathrm{pH}_{\mathrm{opt}}\right)$ was estimated at $\mathrm{pH} 6.0$ and enzyme is more stable in alkali, than in acid. The optimum temperature $\left(T_{\text {opt }}\right)$ for $\mathrm{HRP}$ is $40^{\circ} \mathrm{C}$ and the enzyme is not stable to temperature influence. The horseradish root's extract retains enzymatic activity within 21 days.
\end{abstract}

Keywords: Horseradish peroxidase (HRP), enzyme activity, biocatalytic properties

\section{INTRODUCTION}

Horseradish (Armoracea rusticana Gaerth.) is a rootcrop plant of the Brassicaceae family, one of the oldest known condiments, valued for its extremely pungent, fleshy roots. Roots of this plant are rich in peroxidase, heme containing enzyme belonging to oxidoreductases (EC 1.11.1.7). Applications of horseradish peroxidase (HRP) as noted Hollmann and Arends [1] include removal of peroxide, phenols, amines, indols and other heterocyclic compounds from materials such as food stuffs and industrial waste, as oil refineries, plastics, resins, textiles, iron and steel, forestry industries waste water containing phenolic compounds, synthesis of various aromatic chemicals, in biocatalysis and in radical polymerization. Veitch [2] have reported the decolorization and removal of textile dyes from polluted water and dyeing effluents by using soluble and immobilized peroxidases. Azevedo et al. [3] note that about $82 \%$ of the commercially available HRP is used in kits to test for levels of glucose, uric acid, cholesterol and lactose. Since the 2000s scientists have developed a new method in the treatment of cancer gene-directed enzyme prodrug therapy strategies [3,4] where HRP plays a key role.

In this work we have studied some properties of peroxidase from horseradish acclimatized to severe Mongolian climate and estimated peroxidase activity as well as its biocatalytic properties including $\mathrm{T}_{\text {opt }}$, $\mathrm{pH}_{\mathrm{opt}}, \mathrm{K}_{\mathrm{M}}$, heat inactivation, effects of acid and bases on the stability of HRP.

\section{EXPERIMENTAL}

General: All chemicals used in this study were chemically pure. Reagents for buffer solution, hydrogen peroxide, acids and bases were purchased from Tsetsuuh Trade Co Ltd. (Mongolia). Benzidine was obtained from Sigma-Aldrich (Korea). All experiments were carried out with a 3-5 repetition and average results were taken.

Plant material: Acclimatized horseradish plant samples was collected from Ulaanbaatar area (Mongolia). The roots were stored in a freezer until further studies. For extraction chopped horseradish roots were mixed with a fourfold volume of cold distilled water $(1: 4 \mathrm{w} / \mathrm{v})$ for $30 \mathrm{~min}$ and then filtered. The filtrate was collected and used for the next procedures.

Enzyme assay: Peroxidase activity was measured by A.N. Boyarkin colorimetric assay [5], using benzidine and $\mathrm{H}_{2} \mathrm{O}_{2}$ as substrate. The assay mixture contains 1 $\mathrm{ml}$ of enzyme solution, $2 \mathrm{ml}$ of benzidine (184 $\mathrm{mg}$ of benzidine was dissolved in $200 \mathrm{ml}$ of $0.1 \mathrm{M}$ acetate buffer with $\mathrm{pH}=4.7$ at $60^{\circ} \mathrm{C}$ ) and $1 \mathrm{ml}$ of $3 \% \mathrm{H}_{2} \mathrm{O}_{2}$. Color development rate is measured at $750 \mathrm{~nm}$, after adding $\mathrm{H}_{2} \mathrm{O}_{2}$. Protein concentration was measured by the Lowry method [6] using standard BSA solutions for calibration. One unit (U) of enzymatic activity is defined as the amount of $1 \mathrm{mg}$ enzyme protein which changes extinction of assay mixture in 1 second by 0.001 .

Study of biocatalytic properties: The optimum $\mathrm{pH}$ value for HRP activity was found by assaying enzyme activity at different $\mathrm{pH}(4.0-9.0,0.1 \mathrm{M})$ levels at intervals of 0.5 units. The assay was carried out by taking universal buffer. Optimum temperature value for HRP activity was found by assaying enzyme activity at $20-65^{\circ} \mathrm{C}$ at intervals of 5 degrees and temperature stability was measured at $55^{\circ} \mathrm{C}, 60^{\circ} \mathrm{C}$ and $65^{\circ} \mathrm{C}$. The samples of crude HRP were prepared 
according to the previous procedure and their activities were measured under the circumstances. We determine $K_{M}$ value from the Lineweaver-Burk (or double reciprocal) plot $1 / \mathrm{V}$ from various substrate concentrations (ranging from $1 / 100$ to $1 / 500 \mathrm{M}$, $\mathrm{H}_{2} \mathrm{O}_{2}$ ). Effect of acids and bases on the stability of HRP was found by incubating with acid $(\mathrm{pH}=2.3,4.0, \mathrm{HCl})$ and alkali ( $\mathrm{pH}=8.7,9.7, \mathrm{NaOH})$. Enzyme stability was measured by storing horseradish extract at $20^{\circ} \mathrm{C}, 5^{\circ} \mathrm{C}$ and $-5^{\circ} \mathrm{C}$ for 21 days.

\section{RESULTS AND DISCUSSION}

We have determined HRP activity dependence from the horseradish root diameter (Table 1).

Table 1. Dependence of peroxidase activity from horseradish root diameter

\begin{tabular}{cc}
\hline Root diameter, $\mathrm{mm}$ & Peroxidase activity, U \\
\hline $4.4 \pm 0.1$ & $10.52 \pm 0.48$ \\
$10.6 \pm 0.4$ & $44.36 \pm 1.01$ \\
$19.15 \pm 2.85$ & $14.20 \pm 0.37$ \\
\hline
\end{tabular}

These results show that the enzymatic activity is the greatest in the roots with average dimensions, while in thin and thick roots enzymatic activity decreases. Studies of MacAdam et al. [7], Djakovic and Jovanovic [8] have confirmed that peroxidase activity is directly dependent on the intensity of plant growth, leaf growth parameters as leaf elongation rate and segmental elongation rate. So we believe that the increase in enzyme activity in the roots with average dimensions associated with this process and may be associated with period of plant and root intensive growth.

We have determined $\mathrm{K}_{\mathrm{m}}$ value from the LineweaverBurk plot (Fig. 1).

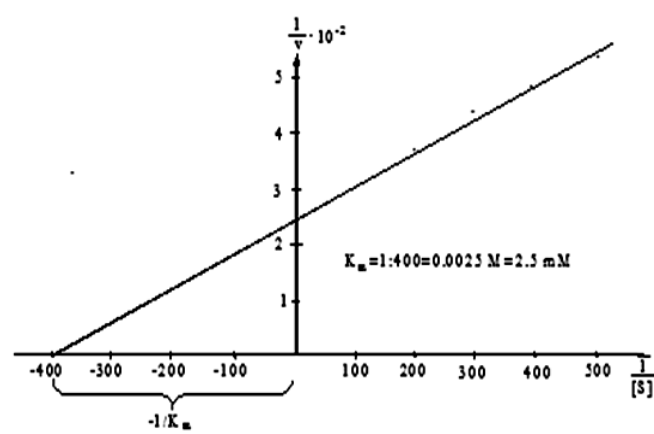

Fig. 1. Lineweaver-Burk plots for HRP activity at various concentrations of $\mathrm{H}_{2} \mathrm{O}_{2}$

From this plot we calculated $\mathrm{K}_{\mathrm{M}}$ value as $2.5 \mathrm{mM}$ and $V_{\max }$ as $5.36 \mathrm{mM}^{-1} \mathrm{~s}^{-1}$. Qiu et al. [9] defined kinetic parameters of HRP and $K_{m}$ value was estimated as $0.43 \mathrm{mM}$ and $V_{\max }$ as $0.35 \mu \mathrm{mol} \cdot \mathrm{min}^{-1} \cdot \mathrm{mg}^{-1}$. This shows that in our case there was an increase of $\mathrm{K}_{\mathrm{m}}$ and $\mathrm{V}_{\max }$ values of peroxidase of acclimatized horseradish.

HRP experienced peak activity $\left(\mathrm{pH}_{\mathrm{opt}}\right)$ at $\mathrm{pH} 6.0$, with $>80 \%$ of the maximum rate observed between $\mathrm{pH} 5.2$ and 7.0 (Fig. 2).

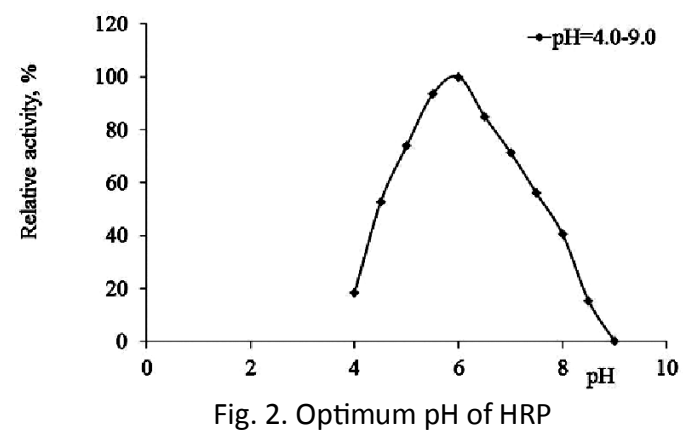

In order to evaluate the stability of HRP in acids and bases HRP incubated over a wide range of $\mathrm{pH}$ $(\mathrm{pH}=2.3,4.0$ for acid stability, $\mathrm{pH}=8.7,9.7$ for alkaline stability) and then the activity was measured (Fig. 3 and 4).

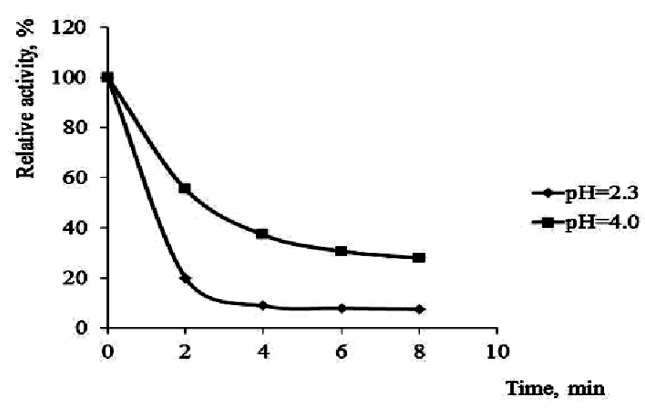

Fig. 3. Acid stability of HRP

From these results we can see that HRP is more stable in alkali, than in acid. In acid peroxidase begins to lose activity after 2 minutes of incubation whereas in alkali peroxidase is stable and retains greater than $50 \%$ (in $\mathrm{pH}=8.7$ relative activity $57.1 \%$ and in $\mathrm{pH}=9.7$ relative

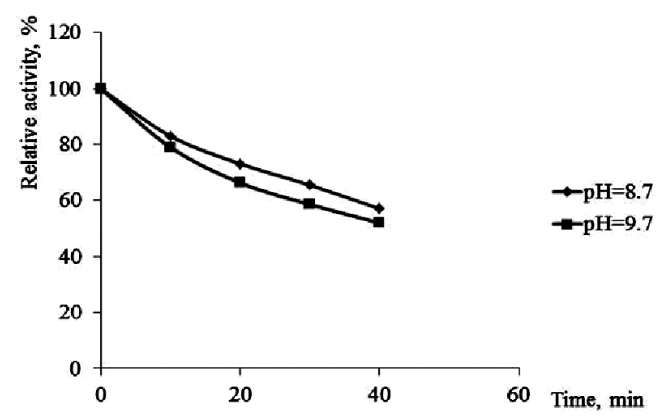

Fig. 4. Alkali stability of HRP

activity 52\%) activity in 40 minutes.

These results are similar to commercial peroxidase which $\mathrm{pH}_{\mathrm{opt}}$ was found at 6.0-6.5 and stable in the $\mathrm{pH}$ range of 5.0-9.0 [10].

Next, we studied the optimum temperature value and thermal stability of peroxidase. HRP show the optimum reaction temperature $\left(\mathrm{T}_{\text {opt }}\right)$ clearly at $40^{\circ} \mathrm{C}$, with $>60 \%$ of the maximum rate observed between $20^{\circ} \mathrm{C}$ and $60^{\circ} \mathrm{C}$ (Fig. 5).

Temperature stability was determined by heating at $55^{\circ} \mathrm{C}, 60^{\circ} \mathrm{C}$ and $65^{\circ} \mathrm{C}$. The results show that after 5 minutes of heating at $65^{\circ} \mathrm{C}$ begins denaturation and inactivation of the enzyme, and at $60^{\circ} \mathrm{C}$ this process 


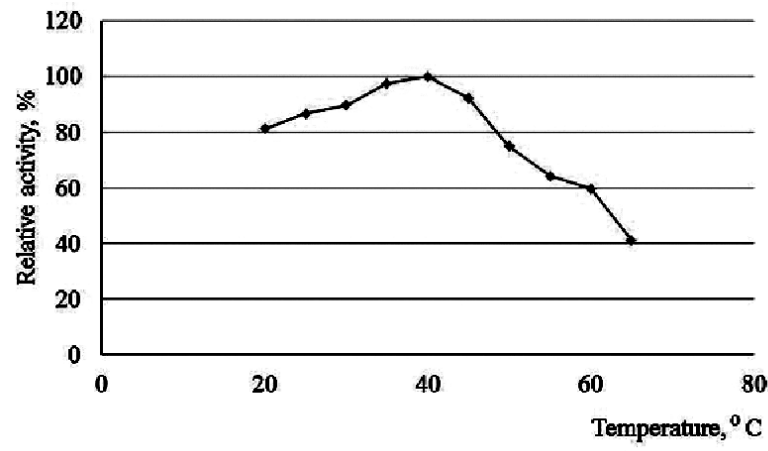

Fig. 5. Optimum temperature of HRP

occurs after 10 minutes and at $55^{\circ} \mathrm{C}$ after 15 minutes of heating, respectively (Fig. 6).

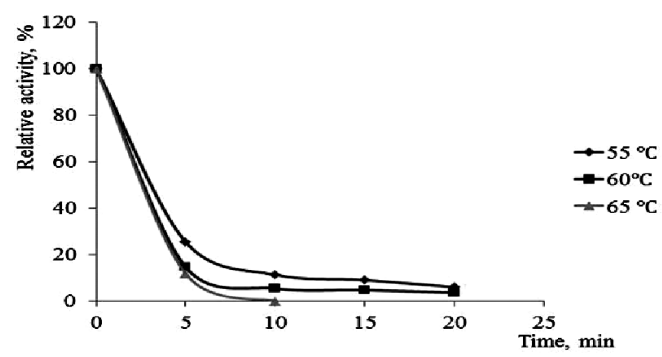

Fig. 6. Temperature stability of HRP

Azevedo et al. [11] determined thermal stability for the soluble enzyme at $\mathrm{pH} 7$ (phosphate buffer) in comparison with immobilized peroxidase in aqueousorganic solvent mixture. The results of this work show that free peroxidase deactivates at $50^{\circ} \mathrm{C}$ with a halflife of 124 minutes. On the other studies Hendrickx et al. [12] investigated the influence of water activity on thermal stability of horseradish peroxidase. The results of this work show that dehydrated enzyme reveals much more thermostability than in solution. Our results confirm these findings and show that horseradish extract peroxidase markedly unstable to temperature influence.

Enzyme stability was measured by storing horse radish extract at $20^{\circ} \mathrm{C}, 5^{\circ} \mathrm{C}$ and $-5^{\circ} \mathrm{C}$ for 21 days and enzyme activity was expressed by relative activity (Fig. 7).

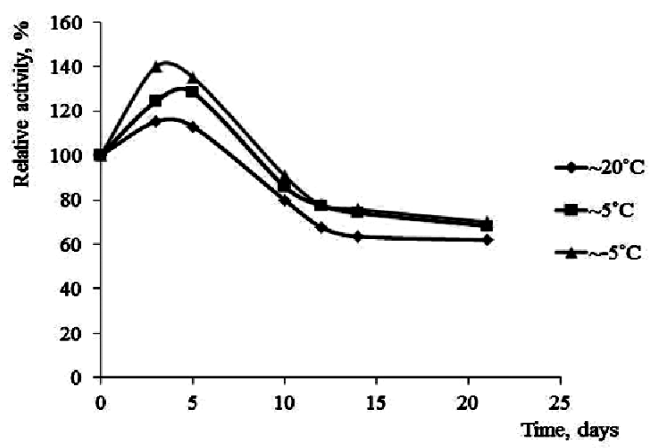

Fig. 7. Enzyme storing stability

During the first three days enzymatic activity is increased by $15.2 \%$ (for $20^{\circ} \mathrm{C}$ ), $28.3 \%$ (for $5^{\circ} \mathrm{C}$ ) and $40.0 \%$ (for $-5^{\circ} \mathrm{C}$ ) respectively. We believe that this may be due to the induction of this enzyme.

\section{CONCLUSIONS}

In conclusion, peroxidase from acclimatized horseradish has kinetic parameters: $\mathrm{K}_{\mathrm{M}} 2.5 \mathrm{mM}$ and $\mathrm{V}_{\max } 5.36 \mathrm{mM} \cdot \mathrm{s}^{-1} \cdot \mathrm{pH}_{\mathrm{opt}}$ of HRP was at 6.0 and enzyme is more stable in alkali, than in acid. $\mathrm{T}_{\text {opt }}$ at $40^{\circ} \mathrm{C}$ and the enzyme is not stable to heat. The horseradish root's extract retains enzymatic activity within 21 days of not depending on the storage temperature.

\section{REFERENCES}

1. Hollmann F., Arends I.W. (2012) Enzyme initiated radical polymerization. Polymers, 4, 759-793

2. Veitch N.C. (2004) Horseradish peroxidase: a modern view of a classical enzyme. Phytochemistry, 65, 249-259

3. Tupper J., Tozer G.M., Dachs G.U., (2004) Use of peroxidase for gene-directed enzyme prodrug therapy with paracetamol. British Journal of Cancer, 90, 1858-1862

4. Azevedo A.M., Martins V.C., Prazeres D.M.F., Vojinovich V., Cabral J.M.S., Fonseca L.P. (2003) Horseradish peroxidase: a valuable tool in biotechnology. Biotechnology Annual Review, 9, 199-236

5. Xu G., McLeod H.L. (2001) Strategies for Enzyme/ Prodrug Cancer Therapy. Clinical Cancer Research, 7, 3314-3324

6. Purev D., Bayarmaa J. (2013) Enzymology. Ed., Udam soyol, Ulaanbaatar, 368-369 (in Mongolian).

7. Lowry O.H., Rosenbrough N.J., Farr A.L., Randall R.J. (1951) Protein measurement with the Folin Phenol Reagent. Journal of Biological Chemistry, 193, 265-275

8. MacAdam J.W., Nelson C.J., Sharp R. (1992) Peroxidase activity in the leaf elongation zone of Tall fescue. Plant Physiology, 99, 872-878

9. Djakovic T., Jovanovic Z. (2003) The role of cell wall peroxidase in the inhibition of leaf and fruit growth. Bulgarian Journal of Plant Physiology, Special Issue, 264-272

10. Qiu H., Lu L., Huang X., Zhang Z., Qu Y. (2010) Immobilization of horseradish peroxidase on nanoporous copper and its potential applications. Bioresource Technology, 101, 9415-9420.

11. Sigma-Aldrich product information. Peroxidase from horse radish

12. Azevedo A.M., Prazeres D.M.F., Cabral J.M.S., Fonseca L.P. (2001) Stability of free and immobilised peroxidase in aqueous-organic solvents mixtures. Journal of Molecular Catalysis, 15, 147-153

13. Hendrickx M., Saraiva J., Lyssens J., Oliveira J., Tobback P. (1992) The influence of water activity on thermal stability of horseradish peroxidase. International Journal of Food Science and Technology, 27, 33-40 